\title{
Exploration and Analysis of Problems and Countermeasures of Cross-cultural Education in College English Teaching
}

\author{
Haiyan Wang \\ School of Foreign Languages, Chengdu University of Technology, Chengdu, 610051, China
}

Key words: college; English teaching; cross-cultural education; cross-cultural awareness; strategy

\begin{abstract}
College English teaching aims to cultivate students' English application ability and communication ability. The final purpose of introducing cross-cultural education in English teaching is to cultivate cross-cultural communication competence of college students. Thus, we must analyze some realistic problems after cross-cultural education is introduced in college English learning, specifying the deep causes including students' cross-cultural awareness and cross-cultural communication competence and put forward corresponding countermeasures to update teaching idea, cultivate cross-cultural awareness and reform teaching methods and evaluation methods. Only in this way, more English talents complying with social needs can be cultivated.
\end{abstract}

\section{Introduction}

Under the situation of global integration, talent competition situation becomes increasingly fierce. Social requirements for talents have transformed to diversified talents from traditional single technology-based or knowledge-based talents. When employing college students, employers greatly boost the requirements for various abilities and qualified. Foreign language level (i.e. cross-cultural communication competence) becomes a significant standard for employers to select talents. So, many universities and higher vocational colleges also introduce cross-cultural education in college English teaching. Cross-cultural education also gives rise to some problems while improving students' cross-cultural communication competence. Exploration of solutions and promotion of intensive application of cross-cultural education in college English teaching have become important topics in current English education researches.

\section{Concept of cross-cultural education}

Cross-cultural education practice appeared early. The researches of cross-cultural educational theory started late and appeared until 1970s. Currently, relatively authoritative definition of the concept of cross-cultural education is the definition in Education Dictionary published in 1998. The dictionary defines cross-cultural education as follows: "cross-cultural education refers to multi-cultural education in the environment where multiple cultures coexist or dominance of one culture supplemented by other cultures; the students growing in a cultural environment receive education in another cultural environment with different languages, customs, habits, values and beliefs; students receive education of non-native language, customs, habits and values through setting up cross-cultural environment. But this definition lacks normative description of the essence of cross-culture and the purpose of cross-cultural education.”[1]

This paper considers cross-cultural education is an educational idea. Cross-cultural education refers to non-native cultural education in allusion to language learners based on certain cultural background through schools, cultural institutions and other media. In this way, language learners can more deeply know and respect the culture they learn and gain better mentality and competence of cross-cultural communication so as to realize the final purpose of cross-cultural communication.

\section{Problems of cross-cultural education in college English education}

\subsection{Students' cross-cultural awareness and cross-cultural communication competence are weak}

Chinese students are strong in written English, but poor in oral expression and communication. Many students are excellent in written English. For example, many students can comprehend English contents during English listening comprehension. They can also read an English article quickly and answer corresponding choice questions according to their comprehension. For the 
questions that students need to select correct words to fill in blanks, students can fill in blanks soon. During writing English compositions, they can apply words and phrases to firm fluent essays with correct grammar and even apply complex sentence patterns better than some foreign students. But, Chinese students will have many problems during communication with others in English. Some students cannot make others understood. Some even cannot speak out. Besides, some topics make foreigners feel embarrassed. The cause for this series of problems is that Chinese students only rest on superficial level during English learning. They do not deeply know cultural connotation of the language so that they do not learn English culture well.

\subsection{Students' native language accomplishment is poor and they do not pay much attention to native language}

Chinese college students generally do not pay much attention to native language culture. For example, they know well foreign festivals, but cannot clearly explain Chinese traditional Spring Festival, Mid-Autumn Festival and other great festivals. They can only know Chinese classical poetry and literary quotations through literal meaning, but know little about Chinese traditional culture, such as Confucianism, Taoism and calligraphy. The main cause of these phenomena is that teachers ignore cross-cultural education in teaching process so that students know little about native culture. Besides, in college English education, people fail to regard language and culture differences as a key point and lack comparison of Chinese and English cultures so that students' cross-cultural accomplishment is low.

In China, English class is set up in the primary school. Teachers mainly teach students to remember and understand words and sentences. However, teachers do not teach them how to apply these words and sentences. Although students have strong English competence, they know little English culture. They cannot master communication method, communication standard and politeness rules. Language mistakes and cultural comprehension deviation often appear, thus bringing bad impression and leading to communication failure. Even those who pass CET-6 will also make such mistakes.

\subsection{English teaching evaluation means are single}

Examination and evaluation links exist in English teaching to test students' learning degree and teachers' teaching level. So, they play important roles in achieving teaching objectives [2]. At present, English teaching lacks systematical cross-cultural communication competence evaluation system. Thus, English teaching cannot be closely connected with cultivation of students' cross-cultural communication competence and just rests on language competence testing stage. Many college students in other disciplines and English teachers learn English in order to pass CET-4 and CET-6. They mainly learn basic English knowledge, including listening, speaking, reading and writing and rarely regard cross-cultural study as the key point. So, we can see it is very necessary for colleges to establish perfect cross-cultural communication competence evaluation system.

\section{Countermeasures to solve cross-cultural education in college English teaching}

\subsection{To enhance cross-cultural education guidance and cultivate students' cross-cultural mentality}

Making students understand and approval different cultures can improve English teaching effects. In English teaching, teachers not just teach students language knowledge, but also compare the differences of Chinese and western cultures and correctly treat different cultures. On the one hand, different cultures should be reflected during setting up English teaching situations so that students can know English culture through interactions between teachers and students and among students, express English culture in correct and vivid form, gain approval and deepen cognition and comprehension of different cultures. On the other hand, students should read more books about English culture or know English culture via movies so as to make students fully feel cultural differences.

Teachers should continuously study different cultures in language, reflect such different cultures in English teaching, fuse research results in cross-cultural teaching and realize transformation of the 
teaching emphasis to study from teaching. Teachers should not just teach students knowledge and answer students' doubts, but also impart good research methods and research topics to students. Students should pinpoint the scope and direction of cross-cultural learning, learn language in language expressions of English articles and know English culture through the contents of articles.

Students should establish correct ideas on English language and cultural learning and should not be blind and arrogant. Meanwhile, students should carry forward Chinese culture. In cross-cultural research, it is required to keep correct cultural view, learn large quantities of original data in English culture with rigorous scientific attitude, carefully analyze and summarize. Meanwhile, students should not constrain approval of different cultures with their own values. Therefore, teachers should leave enough time for students to allow students to learn autonomously and face difficulties and cultivate their cultural education strategy and ability.

\subsection{To promote fusion of different cultures by depending on native culture}

To satisfy external exchange needs, colleges should regard foreign language cultural teaching as main teaching objective. In teaching process, teachers should pay more attention to explaining foreign culture and impart little cultural knowledge of native language. Cross-cultural learning is a process in which different cultures mutually understand, penetrate and fuse. This requires students regarding native language culture as the foundation to learn other cultures. Pure learning foreign culture without comparison of Chinese and western cultures cannot gain good learning effects.

Therefore, in college English teaching, students should fully learn native language culture, comprehend the connotation, deepen comprehension of Chinese and western cultures through comparison, rethink profoundly Chinese culture, cultivate cultural transference ability and realize cross-cultural learning through cultural transference so as to better fusion of Chinese and western cultures. In English education, on the one hand, students should learn foreign language culture and combine language learning and cultural learning; on the other hand, students should carry forward Chinese traditional culture. In college English teaching, students should regard learning of native language culture as important foundation of foreign language learning and fully absorb nutrition of native language culture so as to better fuse different cultures.

\subsection{To introduce cross-cultural teaching and reform teaching methods}

Cross-cultural teaching idea is a new teaching idea. It requires teachers imparting English knowledge to students and explaining connotation of English culture in teaching process so that students can know cultural buckhound of the language, such as national tradition, politeness principle and values. In this way, students can not just learn English, but also learn how to correct use English. In traditional English listening, speaking, reading and writing teaching methods, new teaching methods are added to enrich knowledge background factors [3]. In the face of cultures with different backgrounds, when importing knowledge, teachers should avoid complete "influences of Western culture and civilization”, improve English communication and make students enter English cultural situations in advance to lay the foundation for cross-cultural education.

In English teaching, teachers can use "cultural discussion method" and select significant cultural themes for students so as to make students better conduct cross-cultural learning and enhance understanding of a language culture. When explaining the meaning of a word and a sentence, teachers can adopt "cultural penetration method" and fuse relevant cultural knowledge. Besides, students can use "comparison teaching method" to explain differences between Chinese cultural habits and foreign cultural habits. During simulation drilling, teachers can adopt role playing method to design simulation class and select performance situations reflecting differences between Chinese and western cultures. In this way, students can deepen cognition of foreign culture and improve cross-cultural learning ability through role playing.

\subsection{To value activity guidance and create cultural atmosphere}

Language can reflect cultural background. Learning language and culture should be under certain language environment. Classroom teaching and extracurricular teaching should have specific language atmosphere [4]. Teachers should enrich language teaching environment, add some wonderful and diversified elements and allow students to fully learn language and culture in relaxing and pleasant language environment and feel different cultural connotations. Moreover, 
teachers should design some significant extracurricular activities and encourage students to actively participate. Through participating in activities, students can know customs and habits of foreign culture, accept differences between Chinese and foreign cultures and train their cross-cultural communication competence.

It is required to attach importance to cultural activity guidance and create dense cultural atmosphere. For example, during festivals and holidays, students can organize students to sing English songs and watch pure English movies. Through this way, students can learn cultural knowledge in the process of participating in activities. English communication occasions should beset up in campus, such as English Corner and English Society so that students have enough space for English practice and communication. In addition, teachers can organize students to perform English drama and transform foreign famous stories and novels to stage plays so that students can feel the charm of foreign culture in the performing process. Teachers can also organize English cultural lectures to impart foreign culture, customs and habits so as to add students; language knowledge.

\subsection{To construct diversified evaluation modes and assess students' cross-cultural communication competence}

During cultivating students' cross-cultural communication competence, matched evaluation system should be established. Not only should traditional language competence testing methods be adopted, but also students' cross-cultural learning ability should be examined so as to better evaluate students' cross-cultural communication competence. Cultural testing and evaluation contents are added in the evaluation system, which not just improves teaching effects. Besides, it is also an important means to stimulate students to carry out cross-cultural learning. On the one hand, it is necessary to continuously innovate for examination contents and forms and select some questions which can reflect cross-cultural communication competence in college English grade examination; on the other hand, it is necessary to form perfect evaluation modes, add testing of cross-cultural communication competence and apply multiple methods and forms to conduct diversified evaluation. The specific operation is as follows:

(1) Teachers set up cross-cultural communication situations in teaching process and require students analyzing relevant cases to make them fully utilize knowledge and cultivate their cross-cultural communication competence in relatively real English situations. According to students' performance, teachers can judge students' cross-cultural communication competence and their ability to solve practice problems as the factor to reflect grades.

(2) Teachers can evaluate students through their papers. Teachers can assign some paper topics to let them discuss and study in groups, collect relevant materials, add their own understanding and form papers. Students can adopt PPT to display. Teachers regard the paper and presentation result as the important part of final examination.

In one word, cross-cultural education is required education in foreign language teaching. Teachers must combine students' practical situations to cultivate students' cross-cultural awareness through multi-perspective, multi-layer and multi-dimensional teaching thoughts and ideas so as to make students form good cross-cultural mentality, gradually boost their cross-cultural communication competence through teaching methods and contents full of interest and finally cultivate more qualified cross-cultural communication talents complying with social needs.

\section{References}

[1] Education Dictionary, revised and enlarged version [M]. Shanghai Educational Publishing House, 1998

[2] Zhang huancheng, Construction of cross-cultural teaching mode of college English [J]. Theory and Practice of Education, 2014, 03:56-57

[3] Yuan Xiaolu, Cross-cultural education of college English teachers [J]. Journal of Xi'an International Studies University, 2006, 01:94-96

[4] Wu Zhuang, Wen Weiping, On English as an international language and cross-cultural ability cultivation in English education. Journal of Sichuan International Studies University, 2005, 04:131-134 